\title{
The Effect of STAD Type Cooperative Learning Models and Students' Social Skills on the Fifth Grade Students Learning Outcomes at Cinta Rakyat State Primary School
}

\author{
Sri Astuti ${ }^{*}$, Rachmat Mulyana ${ }^{2}$, Siman $^{3}$ \\ ${ }^{1}$ Postgraduate Program in Universitas Negeri Medan, Indonesia \\ ${ }^{2,3}$ Universitas Negeri Medan, Indonesia \\ emon_astuti@yahoo.co.id
}

\section{Abstract}

This study aims to investigate: (1) the difference in the effect of STAD type cooperative learning model and jigsaw type on the fifth grade student learning outcomes at Cinta Rakyat state primary school, (2) the difference in learning outcomes between students with high social skills and low social skills at grade five and (3) the interaction between cooperative learning approaches and social skills on the learning outcomes of fifth grade students of state primary school. This research is a quasi experimental research. The population of this study is students in class V1, V2, V3 at Cinta Rakyat state primary school. The sample in this study is class Va for the experimental class that is taught by using STAD type cooperative learning and the control class is $\mathrm{Vb}$ which is taught by using jigsaw type cooperative learning. The results show that: (1) the learning outcomes of students who are taught by STAD cooperative learning, 25.70. It is greater than students who are taught by jigsaw cooperative learning, it is 21.83, (2) the learning outcomes of students taught using high social skills obtains an average score of 25.07, while the learning outcomes of students who use low social skills obtains an average score of 22.63, and (3) there is no significant interaction between the use of learning and students' social skills (high, and low) in influencing learning outcomes.
Keywords

STAD type

cooperative learning model; social skills; learning outcomes

\section{Introduction}

As social beings, humans always need others to fulfill their various needs. Humans through their intellect create knowledge as a tool to adapt to the environment. Moreover, culture is created for the needs of the group so that it is called a society. Thinking and reasoning, coexisting, work, and self-control skills (emotions, feelings) are basic skills to survive. These skills are owned by everyone but the development of each individual is different. Efforts to develop social skills optimally and effectively are carried out through the educational process.

Social skills are behaviors that need to be learned, because they allow individuals to interact, get positive or negative responses. Therefore, social skills are very important competencies for everyone, including students. In order to maintain positive social relationships with family, friends, peers and society, the appearance of social problems such as student fights, inter-village fights, drugs and liquor, corruption, disintegration of the nation is a form of weak social skills of individuals, families, communities, even the state. Social skills include the ability to control, adapt, tolerate, communicate, and participate in community life. 
One of the themes taught in elementary schools that are set out in the national goals of the K-13 Curriculum can be realized through learning that emphasizes how students learn. Learning must be changed from the method of knowledge transfer to how students organize their own knowledge. Teacher can realize by creating learning activities that are innovative, fun, meaningful, it will place the teacher as a facilitator, mediator, assessment and direction in learning.

Surya (2011: 54) explains that there are several important aspects that teachers can pay attention to empower children through learning, namely: (1) The importance of understanding in starting learning activities, students already have various conceptions, knowledge that is relevant to what they are learning, (2) Children's activities through various real activities with nature is the main thing in learning; (3) Asking questions is an important part of every lesson, even being the most important part of learning; (4) Learning provides opportunities for children to develop their thinking skills in explaining a problem.

Cinta Rakyat state primary school is a core elementary school in Cinta Rakyat Village, Percut Sei Tuan District. This school is strategically located because it is in the middle of a residential area in Cinta Rakyat Village and it is located on the edge of the city. Based on the results of observations by researchers at the school, it already has adequate learning support facilities such as libraries, student health center and other supporting facilities. The teaching staff at this school has also met teaching standards with the latest undergraduate education including 12 civil servant teachers and 5 contracted teachers. In addition, there are also 10 teachers with civil servant status who already have teacher certificates. In this case, the teachers have tried to provide learning by involving students to actively participate in learning science through assignments. The learning model that is often used by teachers in the classroom is dominated by teachers (Teacher Center) which makes some students feel bored.

The factor of low social skills and student learning outcomes is influenced by several factors. These factors can be divided into two parts, namely internal and external factor. The findings obtained in the observation process, namely; the learning process is centered on the teacher. The learning model used tends to be a direct learning model both on conceptual and factual themes. The theme of the lesson focuses on companion books so that it is less applicable to students' daily experiences. Lack of student learning activity affects the achievement of student learning outcomes that do not reach the minimum completeness criteria, the teacher always focuses on low-level learning outcomes so that students' ability to solve problems, especially open-ended problems, is still very low.

One of the contributing factors to the non-achievement of the minimum completeness criteria score obtained by the students is the implementation of teaching and learning process. Based on the results of observations, the teacher is still teaching using a teacher-oriented approach (Teacher Center Learning), as well as the teacher in conveying themes without thinking about increasing the student's ability to solve problems, especially open-ended problems. From the learning patterns that have been carried out by the teacher so far, learning activities in class $\mathrm{V}$ seem less fun, learning activities are still dominated by teacher activities, and students appear passive in learning activities, besides that students prefer to learn individually so it is indicated that students lack social skills good. This can also have an impact on student learning outcomes in solving problems, especially decreasing open-ended problems.

To be able to improve social skills and student learning outcomes, teachers are required to be more creative in developing learning models that are able to actively involve 
students in the learning process. One way that students can easily learn and foster a spirit of student involvement in learning is by applying a cooperative learning model, where this learning model is carried out in groups.

STAD-type cooperative learning is a way of learning that emphasizes the importance of the natural environment being created in the learning process so that the class is more meaningful because students experience what they are learning for themselves. STAD type cooperative learning is a model that allows students to strengthen, expand and apply their knowledge and academic skills in various kinds of life arrangements both at school and outside of school. In addition, students are trained to be able to solve the problems they face in a situation, for example in the form of simulations, and problems that do exist in the real world.

The application of STAD type cooperative learning greatly help teachers to connect the theme material with real-world situations and motivate students to form a relationship between knowledge and its application with their lives as family members, citizens and workers. STAD-type cooperative learning encourages teachers to select and design a learning environment that allows for linking various forms of social, cultural, and physical experiences.

STAD-type cooperative learning is a learning concept which assumes that children learn better if the environment is created naturally. In other words, learning will be more meaningful if students work and experience for themselves. Learning is not just a transfer of knowledge from educators to students, but how students are able to interpret what they learn. STAD-type cooperative learning encourages students to be more critical thinking. It can improve students' social skills in learning so that in the end the learning outcomes of students will be achieved as targeted, especially in class V Cinta Rakyat state primary school number 104208

In connection with the above description and problems, it is necessary to conduct a study on the effects of the STAD cooperative learning model using concept maps on student learning outcomes. As a comparison, a direct learning model is used.

\section{. III. Review of Literatures}

\subsection{Learning Outcome}

Learning outcome is ability obtained by individual after the learning process which can provide changes in behavior, knowledge, understanding, attitudes and skills of students. Dimyati and Mudjiono (2006: 3) elaborate that learning outcomes are the result of an interaction of learning and teaching actions. Learning outcomes are the realization or expansion of a person's potential skills or capacities. Arikunto (2006: 63) defines that learning outcomes are the results that someone has achieved after attending the learning process by first conducting an evaluation of the learning process that is carried out. Learning outcomes are the level of mastery achieved by students in learning in accordance with the objectives set (Syakur, 2020).

In line with the above opinion, Sudjana (2009: 3) defines student learning outcomes is behavioral changes as a result of learning which covers the cognitive, affective, and psychomotor fields. The value obtained by students is a reference to see student mastery in receiving the theme of the lesson. Jamarah and Zain (2010: 98) explain that learning outcomes are something that students get after learning activities are carried out. Hamalik (2014: 32) states that learning outcomes are the occurrence of behavior changes in a person that can be observed and measured in the form of knowledge, attitudes and skills. 
Based on the theoretical study above, it can be concluded that learning outcomes are changes in behavior as a result of learning in a broader sense covering the cognitive, affective, and psychomotor fields. Operationally learning outcomes are the abilities that students have after receiving their learning experiences. These abilities include cognitive, affective, and psychomotor aspects. Learning outcomes can be seen through evaluation activities that aim to obtain evidentiary data that show the level of student ability in achieving learning objectives. The learning outcomes examined in this study are cognitive learning outcomes which include three levels, namely knowledge (C1), understanding (C2), and application (C3). The instrument used to measure student learning outcomes in cognitive aspects is a test. an active role and more serious attention by various related parties to be able to improve the learning outcomes as expected (Hutagaol, 2020). Explore students' perspectives and evaluate participants in an online classroom with gamification in a business unit to develop actionable recommendations that could be useful in designing curricula (Oe, 2020).

\subsection{Social Skill}

One of the learning objectives is the development of social skill so that students are able to interact with their friends. Moreover, they can complete tasks together. Social skill is the ability to recognize symbolic languages, queue in public places, communicate well with others, cooperate with plural groups, be selective consumers, make decisions, participate as citizens, recognize pluralism, processing and utilizing information (Supriatna, 2007: 130).

Tilaar (2002) defines that social class as a complex set of skills that facilitate successful interactions among peers, parents, teachers and others. Maryani (2011: 18) explains that social skill is the ability to create harmonious social relationships and satisfy various parties, in the form of adjustments to the social environment and solving social problems. Steedly et al (2008: 5) define social skills as a set of competencies that enable individuals to initiate and maintain positive social relationships, contribute to peer acceptance and satisfactory adjustment in school, and enable an individual to cope effectively with the larger social environment.

From the opinion above, it can be concluded that social skill is behavior that support the success of social relationships and allow individual to work with others effectively. Students can learn social skills from individuals of different characters and ages with indicators of interaction skills, communication skills, team / group building skills, and problem solving skills effectively both verbally and nonverbally. The ability to show good behavior and to have good relationships with other people is used by someone to be able to behave in accordance with what is expected by the social.

\subsection{STAD Type Cooperative Learning}

Cooperative learning is a form of learning based on constructivism. Cooperative learning is a learning strategy with a number of students as members of small groups with different levels of ability. Trianto, (2011: 58) defines that cooperative learning is a group of teaching strategies that involves students working collaboratively to achieve common goals. It is structured in an effort to increase student participation, facilitate students with experiences of leadership attitudes and make decisions in groups, and provide opportunities for students to interact and learn with students of different backgrounds. Made (2009) states that there are various elements which are the main provisions in cooperative learning, namely (1) positive interdependence, (2) face to face interaction, (3) 
individual accountability, and (4) skills to build relationships or social skills that are intentionally taught.

There are many types of cooperative learning. One of them is type of Student Teams Achievement Divisions (STAD). Teachers use STAD which refers to student group learning. Present new academic information to students every week uses verbal or text presentations. Students in one class are divided into small groups consisting of 4 or 5 students. Each group is heterogeneous consisted of boys and girls. They have high, medium, and low abilities. Teachers who use STAD refer to student group learning, presenting new academic information to students each week using verbal or text presentations. Team members use activity sheets or other learning tools to complete the theme of the lesson and then help each other to understand the lesson material through tutorials, quizzes and discussions.

\subsection{Jigsaw Type Cooperative Learning}

Cooperative learning is learning by grouping students in the class into small groups so that students can work together with their maximum abilities and learn from each other in the group. Trianto (2011: 58) states that cooperative learning is a learning model that has been known for a long time. It deals with the teacher encourages students to collaborate in certain activities such as discussions or peer teaching. In carrying out the teaching-learning process the teacher no longer dominates as is usual at this time, so students are required to share information with other students and learn to teach each other. Jigsaw type cooperative learning is a type of learning consisting of several members in one group, responsible for mastering part of the learning material and being able to teach that part to his group members. Made (2009) explains that jigsaw is designed to increase students' sense of responsibility for their own learning and also the learning of others.

Based on some of the above theories, it is concluded that the jigsaw type of cooperative learning approach is learning that consists of several members in one group who are responsible for mastering part of the learning material and are able to teach that part to their group members, with students learning in small groups of 4- 6 people. They are heterogeneous and cooperate with positive interdependence and are responsible for the completeness of part of the subject matter that must be studied and convey the material to other group members.

\section{Research Methods}

\subsection{Population and Research Sample}

The population of this study is all students of class $\mathrm{Va}, \mathrm{Vb}$ and $\mathrm{Vc}$ at Cinta Rakyat state primary school academic year 2019/2020 which consisted of 3 (three) classes totaling 90 students. Considering this research carried out treatment and the number of classes is only 2 (two classes) and The research sample is determined by using purposive random sampling technique or selecting samples based on research considerations, namely class $\mathrm{Va}$ for the experimental class which is taught using STAD-type cooperative learning and class $\mathrm{Vb}$ for the control class which is taught using the jigsaw-type cooperative learning.

\subsection{Location and Time of Research}

This research is conducted in class V Cinta Rakyat state primary school, Jl.

Sudirman Gang Desa Cinta Rakyat Village, Percut Sei Tuan District, Deli Serdang Regency. The research lasts for 2 (two) months, from June to July 2020 by considering the following: (1) This school has never conducted research with the problems being studied, 
(2) This school can represent the type of formal school at primary school level, and (3) This school has a problem where the learning outcomes and social skills of students on the theme of animal and human movement organs are still low. This research takes place for two months starting from June to July 2020 with a frequency of 4 (four) meetings. The research time is adjusted to the schedule of the teaching and learning process in class $\mathrm{V}$ at school.

\subsection{Types of Research}

This research is a quasi-experimental research in which there are two sample groups being studied, namely the experimental group and the control group. This type of quasiexperimental research is used since it is difficult to determine which control group is used. Class $\mathrm{V}$ is assumed to have relatively the same characteristics, namely studying in the same semester, relatively the same age, relatively the same environmental conditions and situations, using the same curriculum. The teachers have academics that are assumed to be equal and there are no superior classes. Both of classes have the opportunity to be used as an experimental class (taught with the Student Team Achievement Division (STAD) cooperative learning model and the control class (taught by jigsaw cooperative learning).

\subsection{Data Analysis Technique}

The data analysis technique used in this research is descriptive and inferential statistical techniques. To test the research hypothesis, a two-way ANOVA with a 2X2 factor is used. Variance analysis is an inferential technique used to test the average value assessment. As a variance analysis technique or often referred to as Anava which has many uses.

\section{Results and Discussion}

\subsection{Results}

The main objective of this study is to determine the differences in learning outcomes between students who are taught by STAD cooperative learning model and students who are taught by jigsaw cooperative learning model in the fifth grade at Cinta Rakyat state primary school, to determine the differences in learning outcomes between students with high social skills and students who have low social skills, and to find out the interaction between the jigsaw cooperative learning model and students' social skills on the learning outcomes

Based on the research objectives above, the presentation of the results of this study includes: Analysis of student learning outcomes using cooperative learning type STAD and using cooperative learning type jigsaw at Cinta Rakyat state primary school, as well as analysis of social skills of students using cooperative learning type STAD and students using cooperative learning type jigsaw. To get post-test scores on learning outcomes, a written test is given as many as 28 items of learning outcomes, with a maximum score of 38.

Social skills groups with groups using cooperative learning type STAD and using cooperative learning type jigsaw is a description using cooperative learning type STAD and using cooperative learning type jigsaw. For statements on the points in each indicator, the maximum score is 4 and a minimum of 1 . For statements reject, the score is the opposite of those who accept. From the number of observation items on social skills, it can be seen that as many as 20 observation indicators with an alternative answer to a maximum score of 4 so that the score can be calculated, namely $20 \times 4=80$. As for the learning 
outcomes instrument, the points in each indicator are given a maximum score of 4 and a minimum of 1 . Social skills observation items can be seen as many as 15 observation indicators with the alternative answer to a maximum score of 4 so that the score can be calculated, namely $15 \times 4=60$.

Based on the post-test value data on student learning outcomes using STAD cooperative learning type with using jigsaw cooperative learning, it can be shown by calculating the average value of the student learning result scores for the two groups. The summary results are presented in Table 1 below.

Table 1. Description of the Summary of Results of the Analys is of Learning Outcomes Using Two-Way Anova

\begin{tabular}{|c|c|c|c|c|c|c|}
\hline \multicolumn{7}{|c|}{ Tests of Between-Subjects Effects } \\
\hline \multicolumn{7}{|c|}{ Dependent Variable: } \\
\hline \multicolumn{2}{|l|}{ Source } & $\begin{array}{l}\text { Type III } \\
\text { Sum of } \\
\text { Squares }\end{array}$ & $\mathrm{df}$ & $\begin{array}{l}\text { Mean } \\
\text { Square }\end{array}$ & F & Sig. \\
\hline \multirow[t]{2}{*}{ Intercept } & Hypothes is & 33972.576 & 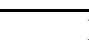 & 33972.576 & 150.810 & 0.052 \\
\hline & Error & 225.268 & 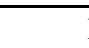 & $225.268^{2}$ & & \\
\hline \multirow[t]{2}{*}{$\overline{\text { CELL }}$} & Hypothes is & 89.376 & 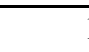 & $\overline{89.376}$ & 89.270 & 0.067 \\
\hline & Error & $\overline{1.001}$ & 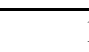 & $1.001^{\mathrm{b}}$ & & \\
\hline \multirow[t]{2}{*}{ KELAS } & Hypothesis & 225.268 & 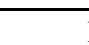 & 225.268 & 225.000 & 0.042 \\
\hline & Error & 1.001 & 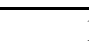 & $1.001^{\mathrm{b}}$ & & \\
\hline \multirow{2}{*}{$\begin{array}{l}\text { CELL * } \\
\text { KELAS }\end{array}$} & Hypothes is & 1.001 & 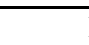 & 1.001 & 0.028 & 0.868 \\
\hline & Error & 1998.089 & 56 & $35.680^{\circ}$ & & \\
\hline
\end{tabular}

Based on the results of data calculations, it can be seen that the learning outcomes of students taught using the STAD cooperative learning type obtained an average value of 25.70 while the learning outcomes of students who are taught by the jigsaw cooperative learning have an average value $=21.83$.

The results of the analysis of variance for both studies show that the fh price of 225,000 is greater than the $\mathrm{fl}$ price of 3,978 at the significant level $\alpha=0.05$ so that H0 is rejected and $\mathrm{Ha}$ is accepted at the significant level $\alpha=0.05$. Thus, it can be concluded that the hypothesis which states taught by using cooperative learning type STAD obtained higher learning outcomes than students taught with cooperative learning type jigsaw, it is tested the truth.

Based on the results of the calculation of the data, it can be seen that students taught using high social skills obtained an average score of $=25.07$, while the learning outcomes of students who have low social skills obtained an average score of $=22.63$. The results of the analysis of variance for the two social skills learning show that the fhrice of 89,067 is greater than the fl price of 3,978 at the significant level $\alpha=0.05$ so that $\mathrm{H} 0$ is rejected and $\mathrm{Ha}$ is accepted at the significant level $\alpha=0.05$. Thus, it can be concluded that the hypothesis which states that there are differences in learning outcomes of students having high social skills with learning outcomes of students having low social skills is verified. 
Based on the results of testing the hypothesis above, it is obtained $f$ h $=0.028$ and the critical value $\mathrm{ft}=3.978$ at the level of $\alpha=0.05$. These results indicate that $\mathrm{fh}=0.028<\mathrm{ft}=$ 3.978 , so it can be concluded that the null hypothesis which states that there is no interaction between learning factors (STAD cooperative type and jigsaw cooperative type) with students' social skills factors (high and low) in influencing student learning outcomes, or if it is seen also the significance level of 0.868 and it turns out that this value is greater when compared to $\alpha=0.05$ or P-value $>\alpha$, so it can be concluded that the null hypothesis which states there is no interaction between learning factors (cooperative type STAD and cooperative type jigsaw) with skill factors students 'social skills (high and low) in influencing student learning outcomes can be accepted. It means that there is no interaction between learning factors (cooperative jigsaw type and STAD cooperative type) and students' social skills (high, and low) in influencing student learning outcomes shown in Figure 1 below. :

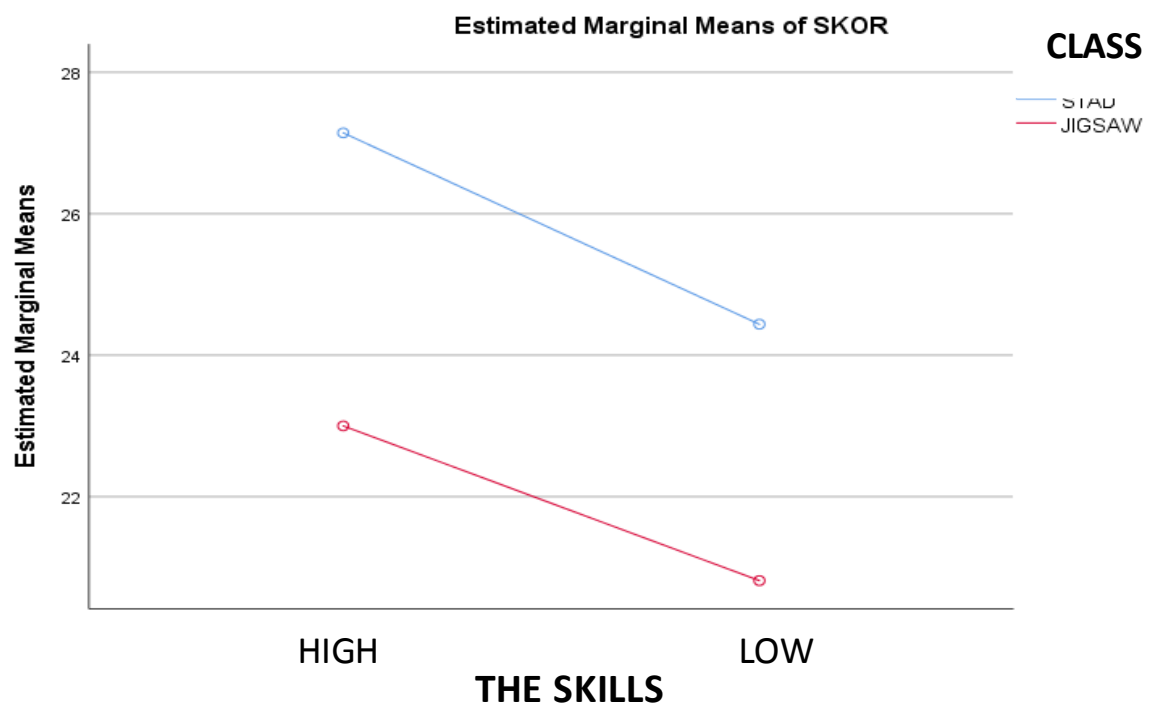

Figure 1. Estimated Marginal Means of Score

Based on Figure 1, it can be explained that learning cooperative type STAD and jigsaw is in accordance with the social skills of students (high and low) in improving student learning outcomes. This can be seen from the average value of each data group that the learning outcomes of students are taught by learning. The STAD cooperative type, namely the high social skills group (27.14), and the low social skills group (24.44) is greater when compared to students who are taught by the jigsaw cooperative learning, namely the high social skills group (23.00) and low social skills group $(20,81)$.

The results show that there is no significantly interaction between the use of learning (cooperative type STAD and cooperative type jigsaw) and students' social skills (high and low) in influencing student learning outcomes. Difference in the average score of student learning outcomes and the average score of social skills (high and low) who are taught by the type of jigsaw cooperative learning simultaneously increased significantly. This shows that learning can accommodate the level of student learning outcomes, namely cooperative learning type STAD can accommodate students 'social skills both high and low. Based on the results of the research analysis, it is known those students' social skills, both high and low. They experience an increase if taught by cooperative learning type STAD. It also identifies that the learning outcomes of students taught with STAD Cooperative learning 
type get "better" benefits compared to students taught with the jigsaw cooperative learning, both those with low and high social skills. This can be shown by the difference in the mean value of student learning outcomes between students taught through the STAD and jigsaw types.

\subsection{Discussion}

Based on the above data collection, it can be concluded that the student learning outcomes using STAD cooperative learning type is higher than student learning outcomes using jigsaw cooperative learning. This is in line with Schunk (2012), constructivism theory is a learning theory that emphasizes the ability of students to build their own knowledge so that students tend to understand and analyze their knowledge. In other words, students who are taught using cooperative learning type STAD get higher learning outcomes than students who are taught with the type of jigsaw cooperative learning.

Through cooperative learning type STAD is expected to stimulate students to think actively to build understanding and ideas to find solutions to problems. This is in accordance with the opinion of Slameto (2003: 43) that says it is more appropriate to use an environment that is close to the lives of students.

In addition, student learning outcomes using cooperative learning type STAD can contain knowledge that is easy and can be imagined by students. This is in accordance with the view that a teaching material can be taught, among others, if it is related to the initial knowledge possessed by students.

The learning process activities are expected that students are able to connect the concepts studied with problems in everyday life. The results of students' thoughts are summarized into concept knowledge, skills and attitudes which are expressed in ideas both orally and in writing to be used in problem solving. It is known that students are trained to use cooperative STAD type which can improve learning outcomes. Learning activities using the STAD cooperative type, each student is given a wide space in giving opinions or ideas without a time limit in solving process. It is known that this learning can transform students into understanding and dealing with a problem and practicing problem solving skills.

Based on the discussion above, STAD cooperative learning is better used in the learning process than jigsaw cooperative learning in terms of solving problems, as well as in taking ideas that can improve learning outcomes. Learning outcomes by using the STAD cooperative type further activate the ability of students' reasoning power and thinking skills so that it allows students to understand more quickly to recognize learning outcomes given by the teacher.

In learning process activities, students who have social skills towards different subject matter are various. There are students who have high social skills and others who have low social skills. It is said that they have high social skills because of their ability to understand and recognize concepts and analyze the material provided so well in understanding the material given. This means that once the teacher explains the students are happy, enthusiastic and understands what the teacher explains to students and it can be absorbed properly. The social skills of students who use cooperative learning type STAD are higher than social skills of students who use cooperative learning types of jigsaw. By using cooperative learning type STAD, students find it easier to improve learning outcomes

People who have high social skills, they tend to be fond of thinking, conceptualize and analyze information. They have a high regard for organized and tidy people. It is easy 
for them to telescope important matters such as key points and important details. The differences that students have demands are different treatment in the grouping of students and the treatment of teachers in teaching. The attitude and appearance of students in the learning process are aspects that affect learning. Based on the explanation above, it is clear that the social skills of students who use STAD cooperative learning are one of the factors that influence the learning process. This means that students using cooperative learning type STAD have better social skills than students who use cooperative learning type jigsaw.

The analysis results obtained, there are differences in the interaction of learning and social skills of students in influencing student learning outcomes. On average, groups of students who have high social skills and are taught using STAD cooperative learning have higher learning outcomes than using jigsaw cooperative learning. The average learning outcomes of the group of students who have low social skills and are taught with the STAD cooperative learning type are lower than the group of students who have low social skills but are taught by using the jigsaw cooperative learning type. In other words, groups of students who have low social skills are better at using the Jigsaw cooperative learning type compared to using STAD cooperative learning, although the difference in learning outcomes is not significant. So, in this case the learning and social skills of students are significant enough to influence student learning outcomes at Cinta Rakyat state primary school

In this study, the internal factors are social skills, namely learning outcomes in the form of pretest and posttest and emotional in the form of student learning activities, while the external factor is the use of the learning model by the teacher. The learning model is one of the important factors to achieve success in the learning process. The innovative learning model can activate students in learning so that the learning atmosphere will feel more alive. Rusman (2010: 202) defines that cooperative learning type STAD is a form of learning in the way students learn and work.

Based on the overall student learning outcomes, there is an increase in the ability of students before treatment and after treatment, especially in the cooperative learning treatment type STAD. Whereas in the jigsaw cooperative learning class, there is an increase in average learning outcomes. This is lower than the average value that has been carried out by students using STAD cooperative learning.

\section{Conclusions}

Based on the results of the research and discussion previously stated, several conclusions can be drawn below: (1) the learning outcomes of students who taught by STAD cooperative learning is 25.70 greater than students who taught by jigsaw cooperative learning by 21.83 . It can be seen that the student learning outcomes using the STAD cooperative learning type is higher than the student learning outcomes using the jigsaw cooperative learning. Through cooperative learning type STAD is expected to stimulate students to think actively to build understanding and ideas to find solutions to problems, (2) the learning outcomes between students who have high social skills and students who have low social skills. It can be seen that the learning outcomes of students taught using high social skills obtained an average value $=25.07$, while the learning outcomes of students who use low social skills score average $=22.63$. Based on this, it is concluded that the learning outcomes between students who have high social skills are higher than students who have low social skills; and (3) The results show that there is no significant interaction between the use of learning and students' social skills (high, and 
low) in influencing learning outcomes. STAD is the high social skills group (27.14), and the low social skills group (24.44), it is greater than students who are taught by Jigsaw cooperative learning, it is the high social skills group (23.00), and the low social skills group.

\section{References}

Arikunto, S. 2006. Qualitative Research Methods. Jakarta: Bumi Aksara.

Djamarah, Syaiful Bahri and Aswan Zain. 2010. Teaching and Learning Strategy. Jakarta: Rineka Cipta.

Dimyati and Mudjiono. 2006. Learning and Learning. Jakarta: PT Rineke Cipta.

Hamalik. 2014. Teaching and Learning Psychology. Bandung: Sinar Baru Algensindo.

Hutagaol, R., Saragih, A.H., and Siagian, S. (2020). The Effect of Participative Learning Strategy and Interpersonal Communication on Results of Civic Learning Education. Britain International of Linguistics, Arts andEducation(BIoLAE) Journal Vol. 2 (2): 515-524.

Made, Wena. 2009. Contemporary Innovative Learning Strategies: An Operational Conceptual Review. Jakarta: Bumi Aksara.

Maryani, Enok. 2011. Development of Social Studies Learning Program for Increasing Social Skills. Alfabeta: Bandung.

Oe, H., Takemoto, T., and Ridwan, M. (2020). Is Gamification a Magic Tool?: Illusion, Remedy, and Future Opportunities in Enhancing Learning Outcomes during and beyond the COVID-19. Budapest International Research and Critics in Linguistics and Education (BirLE) Journal Vol 3 (3): 1401-1414.

Rusman. 2010. Learning Models (Developing Teacher Professionalism Second Edition). Jakarta: Raja Grafindo Persada.

Scunk, Dale H. 2012. Learning Theories (Theories of learning: educational perspectives). Yogyakarta: Student Library.

Slameto. 2003. Learning and the Factors Affecting It. Jakarta: Rineka Cipta.

Sudjana, Nana. 2009. Assessment of Teaching and Learning Process Results, Bandung: Remaja Rosda Karya.

Supriatna, Nana, et al. 2007. Social Studies Education in Primary School. Bandung: UPI Press.

Sun. 2011. The Right Strategy to Achieve Learning Success. Jakarta: Elex Media Komputindo.

Steedly, Kathlyn M. et al. 2008. Social Skills and Academic Achievement. Journal of NICHY Evidence for Education, 3 (2), 1-7.

Syakur, A. et al. (2020). The Effect of Project Based Learning (PjBL) Continuing Learning Innovation on Learning Outcomes of English in Higher Education. Budapest International Research and Critics in Linguistics and Education (BirLE) Journal Vol 3 (1): 625-630.

Trianto. 2011, Constructivitis Oriented Innovative Learning Models. Jakarta: Presetasi Pustaka.

Tilaar, H.A.R. 2002. Social change and education: An introduction to transformative pedagogy for Indonesia. Jakarta: PT Gramedia. 